\title{
「ロボットの三次元環境認識と行動生成」 特集について
}

映画やアニメに描かれているロボットは, 人間が生活す る空間で人間と同じょうに動くことができる，例えば，扉 を開けて部屋の中に入り，散らかった本を見つけると，本 棚に片付けてくれる.もし本当に, 散らかった部屋を掃除 してくれるロボットがいたら，主婦やお年寄り，忙しい研 究者にとっては非常に助かる存在となるだろう。実際に, これまでに行われたアンケート調査でも，ロボットにやっ て欲しい作業は，掃除や身の回りの整理であった。

この一見単純そうな作業をロボットが実現するために は，数多くの要素技術を必要とする．まず，ロボットが部 屋という空間や, 部屋の中に存在する本や本棚などの物体 を三次元で認識する必要がある．また，一旦認識した本や 棚などの情報は, 人間が日々の生活で使うことで位置や状 態が変化するため，それに合わせて認識した情報を更新し なければならない，その上で，目的を達成するための動作 を, 作業内容や周辺の物の位置関係に応じて計画する必要 がある.

そこで，本特集では「ロボットの三次元環境認識と行動 生成」と題して, ロボットが三次元空間で自律的に環境を 認識し行動を行うための取り組みを紹介する，最初に，立 命館大学の白井良明氏から「三次元環境認識と行動計画の 歴史と展望」と題して, 人間と共存して作業を行うロボッ 卜を想定した場合に考えられる課題を明らかにし，環境認 識と行動計画に必要な要素技術について研究の歴史をわか りやすく概観していただいた，さらに，今後発展が期待さ れる未解決の問題に関しても展望していただいた。

次に, ロボットが三次元空間で作業を行うために必要な, 三次元空間の認識，その中を移動する人間の検出・追跡, 作業対象となる三次元物体の認識について, レーザー距離 センサやカメラを使った研究を取り上げた. 東北大学の大 野和則氏, 竹内栄二朗氏, 筑波大学の坪内孝司氏からは 「投光型距離センサを用いた三次元 SLAM」と題して，レ ーザー距離センサを用いた未知空間の三次元地図構築と位 置推定の概要, 各要素技術の取り組みに関して解説してい ただいた，産業技術総合研究所の加賀美聡氏からは「ステ レオカメラからのオンライン三次元 SLAM」と題して, ス テレオカメラを用いた環境の三次元地図構築の概要と, リ アルタイムでロバストな解法に関して解説していただい た. 九州大学の倉爪亮氏からは「三次元空間での移動物体 の追跡」と題し，ロボットや環境に設置したカメラやレー
ザー距離センサを用いた移動物体の検出・追跡技術に関し て解説していただいた．千葉工業大学の友納正裕氏，東京 大学の山崎公俊氏からは「三次元物体のモデリング・認識 とロボティクスへの応用」と題して，カメラを用いた三次 元物体モデル生成と物体認識, 認識に基づく物体操作やナ ビゲーションなどに関して解説していただいた。

また，ロボットが認識した情報に基づいて行動する際に 必要な, 認識した情報の確かさに応じて動作を計画する研 究や, 空間の広さに応じてロボットの姿勢を計画し, 作業 の目的に応じて物体を認識し，複数の動作を組み合わせて 作業を実現する研究を取り上げた。豊橋技術科学大学の三 浦純氏からは「移動ロボットの環境認識と行動生成」と題 して，環境認識にかかるコストと得られる環境情報の確か さに応じて, 認識制御を含めた最適な行動計画を行う取り 組みに関して解説していただいた，産業技術総合研究所の 金広文男氏からは「ヒューマノイドロボットの環境モデル と歩行計画」と題して, 三次元グリッドマップを用いた空 間記述による，門をくぐるような三次元障害物を考虑した 歩行計画に関して解説していただいた，東京大学の岡田慧 氏からは「日常生活支援ヒューマノイドの環境認識・行動 制御」と題して, 知識ベースに基づく物体や道具の認識, 認識に基づくヒューマノイドの行動生成, 認識した物体を 確率的知識として記憶する枠組みに関して解説していただ いた。

環境認識技術は，自動車を含めた移動機械全般に深く関 係する.トヨ夕自動車株式会社の北浜謙一氏, 松原利之氏, 塚田明宏氏, 平野豊氏, ナレッジネット株式会社のフラン ク ガルパン氏から「自律移動機械のための環境認識」と 題して, 移動機械の環境認識に関する課題と要素技術, シ ステム構築例について解説していただいた。

以上, 本特集号では, 実世界で作業を行うロボットにと って必要不可欠な「環境認識と行動生成」に関して, 空間 の認識, 物体の認識, 移動する人間の認識・追跡, 認識に 基づく動作生成, 認識した情報の構造化など幅広い技術を 紹介した。

最後に, 年末年始の忙しい時期にもかかわらず執筆して くださった先生方に心から㧍礼申し上げます，皆様のおか げで，有意義な特集号を完成させることが出来ました。

（大野和則 東北大学, 友納正裕 千葉工業大学) 